\title{
| Productivity in Sheffield City Region
}

Christina Beatty

Steve Fothergill

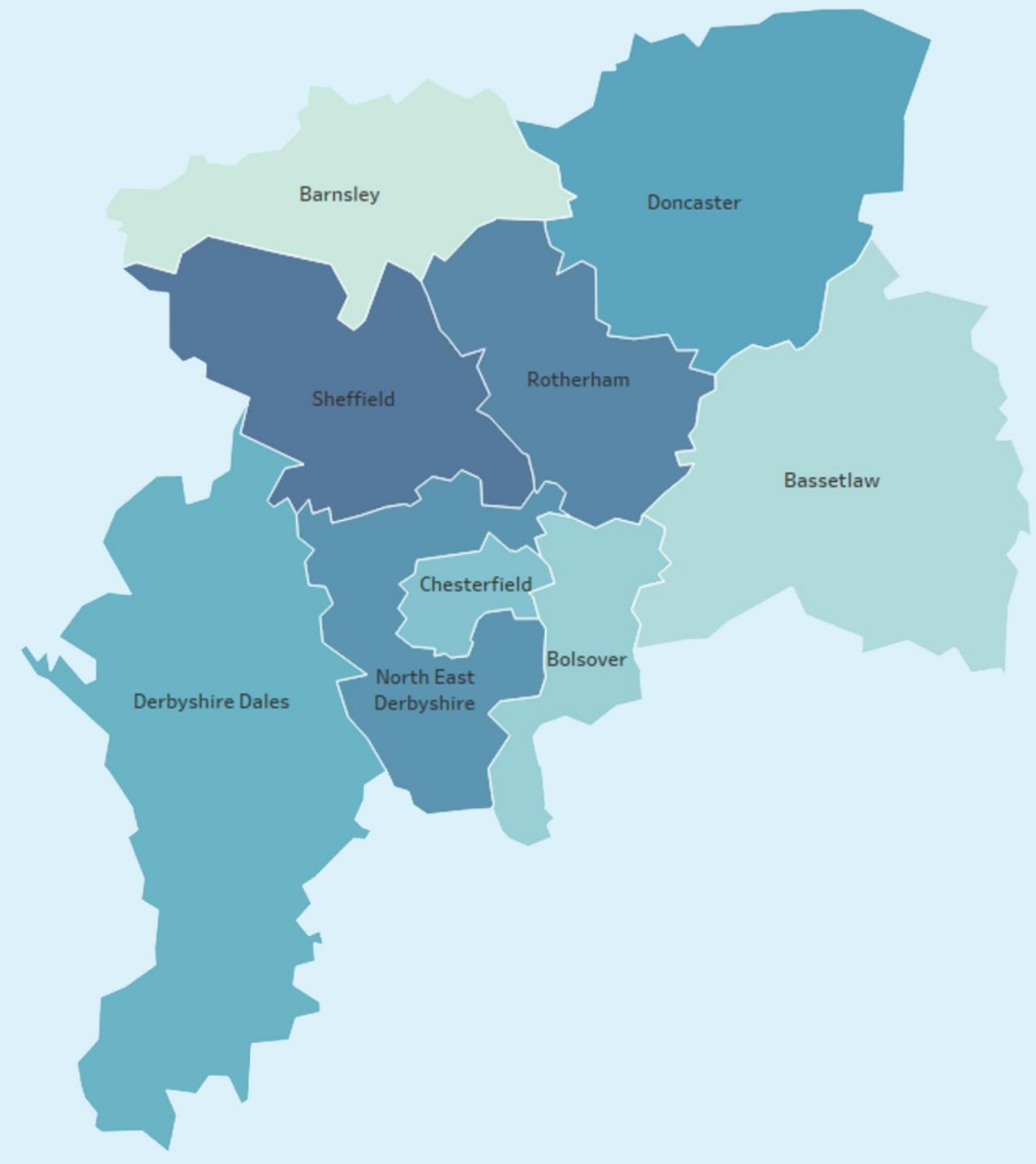




\title{
PRODUCTIVITY IN SHEFFIELD CITY REGION
}

\author{
Christina Beatty and Steve Fothergill \\ Centre for Regional Economic and Social Research \\ Sheffield Hallam University
}

May 2020 


\section{Summary}

This report presents a range of measures of productivity in Sheffield City Region, including innovative estimates of the efficiency of production in the local economy which adjust for the mix of industries, occupations and hours worked. The report compares Sheffield City Region with other parts of the country, looks at the trends through time and examines the differences between local authorities and industries within the city region.

- Although output per head and output per job in Sheffield City Region are both well below the UK average, the efficiency of production in the local economy is far closer to the average

- In terms of efficiency, Sheffield City Region is not out-of-line with England's other main urban areas outside London but there is no evidence that the city region is catching up with the UK average

- Efficiency levels appear to be broadly similar across the larger local authorities within the city region

- There is substantial variation in productivity between industries within the city region, with some matching national levels but others far behind

- Sheffield City Region's manufacturing sector, in particular, has low levels of productivity that are potentially concerning

The report concludes that raising productivity in the city region requires more jobs and better jobs. The report also argues that the low productivity in the city region's manufacturing sector requires further research.

\section{Acknowledgement}

This research was financed by Sheffield Hallam University from funds allocated by UKRI Research England 


\section{PRODUCTIVITY IN SHEFFIELD CITY REGION}

\section{Introduction}

This report looks at productivity in the Sheffield City Region. It presents a range of indicators, including an innovative measure of the efficiency of local production. It compares Sheffield City Region with other areas, charts the trends over time and examines the variation between local authorities and industries.

Productivity has become central to debates about regional and local differences in prosperity. The UK government's aspiration to 'level up' the regions has become less about creating more jobs in the poorer parts of the country - though that remains part of the jigsaw - and more about raising productivity, in particular by narrowing the gap with London and South East England. If the gaps in productivity can be narrowed, the argument goes, the regions will be more prosperous, the UK economy as a whole will be more productive and living standards will be higher.

For the moment, of course, concerns about productivity have been submerged by the coronavirus crisis and its damage to the economy. But as the UK emerges from the crisis there is no reason to suppose that the big local and regional differences in productivity will have gone away. The post-crisis world will inherit much the same capital stock, workforce and infrastructure that was previously in place across the country - and with it, no doubt, much the same gaps in productivity. Alongside interventions to mitigate the economic impact of the crisis, policies to address the long-term structural weaknesses of regions and local areas will still be needed.

In a 2019 report $^{1}$ we challenged the way that local differences in productivity are conventionally measured and understood. The report presented a range of productivity indicators for each sub-region in the UK and for each of the main regional cities, from 'output per head' and 'output per job' through to a new measure of the 'efficiency' of production in each area which adjusted for the local mix of industries and occupations. The conclusion of this exercise was striking: despite the big differences across the country in output per head and per job, the differences in the efficiency of production across the UK appear to be far more modest.

In the present report on Sheffield City Region we have taken the analysis several steps further:

\footnotetext{
${ }^{1}$ C Beatty and S Fothergill (2019) Local Productivity: the real differences across UK cities and regions, CRESR, Sheffield Hallam University.
} 
- All the productivity measures are updated to 2018 (the most recent year for which official statistics on local output are available)

- The measures of productivity are extended back in time to 2004 , to identify local trends

- The measures of productivity for the city region are disaggregated down to local authority level

- The variation in productivity between industries within the local economy is explored

We have piloted all these additional measures of productivity here in the context of Sheffield City Region. A further report, extending the methods to the rest of the UK, is planned for later this year.

\section{Disaggregation of productivity}

In our 2019 report we disaggregated the variation in local productivity into component parts. We follow the same approach here for Sheffield City Region.

\section{Gross Value Added (GVA) per head}

This is our starting point. GVA per head is the value of production in an area in relation to its population. GVA per head should not be confused with productivity in the sense of 'efficiency' or 'output per job' but it is a legitimate and useful measure of the value of economic activity that takes place in an area in relation to its resident population. Its close relative, GDP per head, is used by the EU to allocate funds for regional development, including substantial funding to the UK up to the end of 2020. The GVA figures we use, and the population data, come from the Office for National Statistics (ONS).

\section{GVA per head less imputed rent}

This is a measure of productivity that strips out the small part of GVA that is not the result of the input of labour. 'Imputed rent' is the value of housing services accruing to owner-occupiers - in effect, the rent they would have had to pay if they had not owned their property - and is conventionally included in GVA and GDP, especially to facilitate international comparisons, but it distorts comparisons of productivity between local areas within the UK because of variations in housing tenure and costs. We therefore exclude imputed rent from all the further measures of GVA described below. The figures on imputed rent come from ONS. 
This expresses GVA in relation to the resident working age population rather than in relation to the population as a whole. This is relevant because different parts of the UK have different proportions of the population above and below working age and, because most under-16 and most-over 65 don't participate in the labour market, it makes sense to look at production in relation to the working age population. The population data again comes from ONS.

\section{GVA per employed resident}

Not all working-age residents are in work of course, and some over-65s remain in employment. Expressing GVA in relation to the employed resident population takes account of the differences in employment rates across the country. In practice the main working-age groups not engaged in paid employment are students, men and women out of the labour market on disability benefits, and women at home with children. Prior to the coronavirus crisis, the unemployed have for a number of years tended to be a smaller group. Estimates of the employed resident population (aged $16+)$ in each area come from the UK's Annual Population Survey.

\section{GVA per filled job}

GVA per filled job is one of two ONS measures of local productivity (the other is GVA per hour worked). The GVA figures here are taken from ONS but exclude imputed rent. The jobs are those located in the area and this measure of productivity therefore adjusts for commuting, because the number of jobs in each area is not necessarily the same as the number of local residents in work. GVA per filled job also adjusts for double-jobbing (when some individuals hold two or more jobs).

\section{GVA per job adjusted for industry mix}

Different industries have different levels of output per head, and the mix of industries varies from place to place. We therefore calculate what would have been each area's GVA per job if each industry in the area had the UK average GVA per job for that industry. Here we disaggregate all workplace employment into eight different industries ${ }^{2}$, again using ONS data. We then deduct the industry effect from the GVA per filled job.

\footnotetext{
${ }^{2}$ SIC sections A, B, D \& E (Agriculture, Mining, Electricity, Gas, Water and Waste), C (Manufacturing), F (Construction), G \& I (Retail, Distribution, Hotels and Restaurants), H \& J (Transport and Communications), K, L , M, \& N (Banking, Finance and Business services), O, P \& Q (Public administration, Education and Health), R, S \& T (Other services). Sources: Workplace employment by area, 2011 Census of Population; GVA per employee by industry 2018, ONS. Data on workplace employment by industry for later years is either subject to sampling error (APS) or omits large numbers of self-employed (Business Register and Employment Survey) and is therefore unsuitable for this exercise.
} 
Within each industry there are 'spatial divisions of labour': managers and professionals tend to be located more in some places (e.g. London) whereas the workers undertaking routine production or delivering routine services are more prevalent elsewhere. This boosts GVA per job in the places where managers and professionals are located (because their higher pay is counted as higher output) and lowers the figures where they are a smaller proportion of the workforce. We calculate what would have been each area's GVA per job if each occupational group ${ }^{3}$ within each industry had the UK average GVA for that occupation. As a proxy for GVA per person in each occupation we use UK average gross hourly earnings of employees in each occupational group from the ONS Labour Force Survey. The impact of occupational mix is the difference between the impact of industry mix (see earlier) and the expected GVA per job in each area resulting from this second calculation.

\section{'Efficiency factor'}

The final adjustment is for differences between places in average hours worked. ONS publishes data on hours worked in each area, allowing the necessary adjustment. The resulting figure is what we have termed the 'efficiency factor' - the productivity of workers in each area after having adjusted for the mix of industries, the mix of occupations and hours worked. Unlike GVA per filled job, which simply counts the value of production per worker, the 'efficiency factor' measure s how well the production of goods and services is carried out in each location.

At each step in this exercise the productivity in Sheffield City Region (and, later in the report, in its constituent local authorities and comparator areas) is expressed in relation to the national average as an index number where $\mathrm{UK}=100$.

The 'efficiency factor' nevertheless comes with a health warning: these are estimates based on the cumulative effect of a number of calculations and inevitably subject to a margin of error. In particular, it is unlikely that the adjustments for industry and occupation, based on just eight industry groups and nine occupational groups, are able to take full account of each of these factors.

\footnotetext{
${ }^{3}$ (1) Managers, directors and senior officials, (2) Professional occupations, (3) Associate professional and technical occupations, (4) Administrative and secretarial occupations, (5) Skilled trades occupations, (6) Caring, leisure and other service occupations, (7) Sales and customer service occupations, (8) Process, plant and machine operatives, (9) Elementary occupations. Source: Workplace employment by area, 2011 Census of Population.
} 


\section{Sheffield City Region: overview}

For Sheffield City Region the different measures of productivity are shown in Figure 1. This disaggregation, for 2018 , is important in understanding the local economy and worth describing:

- GVA per head: $69 \%$ of UK average

Overall output per head in the Sheffield City Region economy is barely two-thirds of the national average.

- GVA per head less imputed rent: $70 \%$ of UK average

This adjustment makes little difference. Excluding imputed rent tends to make a bigger difference in the parts of the country with high house prices and high owneroccupation.

- GVA per 16-64 year old: $70 \%$ of UK average

Shifting to this measure, based on the working age population, also makes little difference, reflecting the fact that Sheffield City Region's population structure is close to the national average.

- GVA per employed resident: $72 \%$ of UK average

On this measure Sheffield City Region is a little closer to the national average because the area has an above-average share of adults of working age who are not in work.

- GVA per filled job: $80 \%$ of UK average

This brings Sheffield City Region considerably closer to the national average. The increase compared to GVA per employed resident is mainly likely to reflect net out commuting (e.g. to Manchester, Leeds, Nottingham) from the city region as a whole.

- GVA per job adjusted for industry mix: $85 \%$ of UK ave rage

Adjusting for the mix of industries, productivity in Sheffield City Region moves closer to the national average. This reflects a local mix that is biased towards sectors that have below-average productivity across the UK as a whole.

- GVA per job adjusted for industry and occupational mix: $91 \%$ of UK ave rage Again, Sheffield City Region moves substantially closer to the national average. This reflects an occupational structure within each industry that is biased towards lowergrade, lower-wage occupations.

- 'Efficie ncy factor': 92\% of UK ave rage

The final adjustment (for hours worked) nudges Sheffield City Region still closer to the national average, though still below par. This suggests that the efficiency with which goods and services are produced in the sub-region is on average around 8 per cent below the national average. 
Figure 1: Productivity in Sheffield City Region, 2018

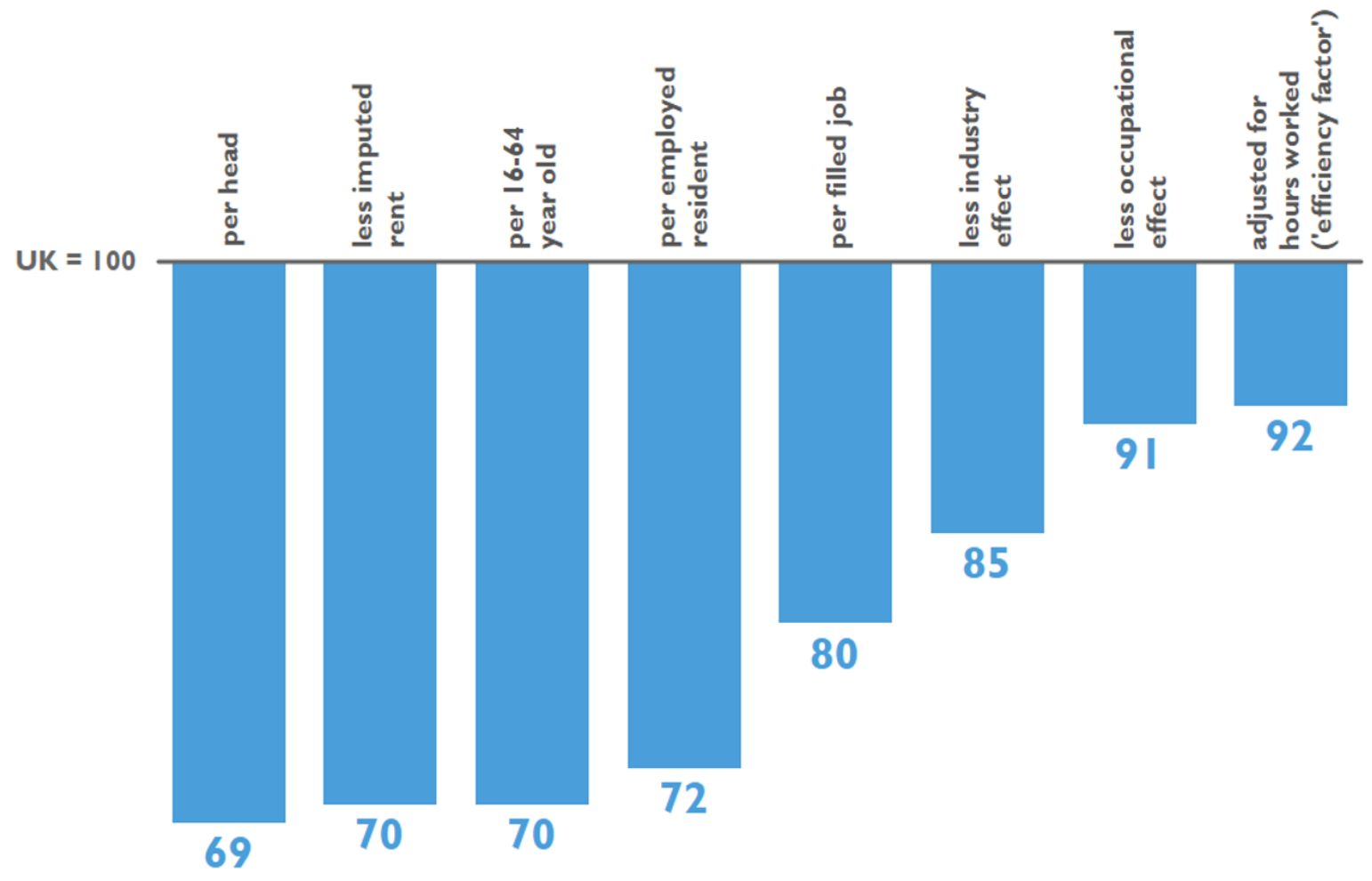

Sources: APS, ONS and Sheffield Hallam University

These figures offer key insights into the nature of Sheffield City Region's 'productivity problem'. Regarding the shortfall in local GVA per head compared to the national average:

- Roughly 35 per cent is attributable to population structure, employment rates and net commuting

- A further 40 per cent is attributable to the industrial and occupational structure of the local economy and (to a lesser extent) hours worked

- Only the remaining 25 per cent appears to be attributable to a shortfall in the efficiency of production

Regarding the shortfall in Sheffield City Region's GVA per filled job compared to the national average:

- Roughly 25 per cent is attributable to the local mix of industries

- A further 30 per cent is attributable to the local occupational structure

- 5 per cent reflects hours worked

- The remaining 40 per cent appears attributable to a shortfall in efficiency 
Again, a health warning needs to be attached to these estimates of below-average efficiency. Given the methods applied here, which include a relatively simple breakdown by industry and occupation, it is likely that the full effects of industrial and occupation structure are underestimated and, by implication, that the shortfall in efficiency in the city region is over-estimated.

Nevertheless, it is an important conclusion that the big gaps in GVA per head and in GVA per filled job between Sheffield City Region and the UK average appear to be due only partially to a shortfall in 'efficiency'. Structural factors account for a much larger share of the gap.

That structural factors lie at the root of Sheffield City Region's low productivity is a conclusion we reached in our earlier report ${ }^{4}$, based on data for 2017 . It is also a conclusion that we found applies to most other parts of the UK: the big local differences in GVA per head and in GVA per filled job are not matched by big differences in the efficiency of production. In a relatively small country, with a fairly free flow of labour, capital and knowledge between places this is perhaps not entirely surprising even if there are still residual local differences in productivity.

The importance of structural factors is reinforced by a recent study commissioned by the UK Core Cities from the OECD ${ }^{5}$. This estimated the potential productivity gains if the workforce characteristics (i.e. skills) and sector composition in Core Cities were to adjust to the UK average. The data sources and methods differed from those deployed here for Sheffield City Region and the overlap between 'skills' and 'occupation' is far from perfect, though there is clearly a correlation. However, the conclusions are remarkably similar. The OECD study estimated that in the Sheffield 'functional urban area' productivity would be between 9 and 10 percentage points higher if these structural factors converged to the national average. Our estimate is that Sheffield City Region's industrial and occupational structure together account for a 10 percentage-point gap between local and national productivity.

The Office for National Statistics has also recently begun to explore how the differences in productivity between industries feed through into differences in productivity between places ${ }^{6}$. The ONS study notes that there appear to be important effects, though at this stage the analysis has not been carried out below the level of standard statistical regions (e.g. Yorkshire \& the Humber).

\footnotetext{
${ }^{4} \mathrm{C}$ Beatty and S Fothergill (2019) op. cit.

${ }^{5}$ OECD (2020) Enhancing Productivity in UK Core Cities: connecting local and regional growth, OECD Publishing, Paris.

${ }^{6}$ Office for National Statistics (2020) Regional labour productivity, including industry by region, UK: 2018, ONS, London.
} 


\section{Comparison with other areas}

Table 1 compares alternative measures of productivity in Sheffield City Region with similar figures for the Local Enterprise Partnership (LEP) areas covering England's other main cities. The figures here are taken from our earlier report ${ }^{7}$ and have not yet been updated from 2017 to 2018. However, the figures for Sheffield City Region differ little between the two years.

Table 1: Productivity in selected LEPs, 2017

\begin{tabular}{lrrr}
\hline & $\begin{array}{r}\text { GVA per } \\
\text { head } \\
\text { UK=100 }\end{array}$ & $\begin{array}{r}\text { GVA per } \\
\text { filled job } \\
\text { UK=100 }\end{array}$ & $\begin{array}{r}\text { 'Efficiency } \\
\text { factor' } \\
\text { UK=100 }\end{array}$ \\
\hline London & 179 & 141 & 111 \\
West of England* & 108 & 97 & 96 \\
Greater Birmingham \& Solihull & 92 & 96 & 99 \\
Greater Manchester & 87 & 90 & 92 \\
Leeds City Region & 83 & 87 & 91 \\
Derby, Derbyshire, Nottingham \& Notts & 78 & 85 & 93 \\
Liverpool City Region & 76 & 89 & 99 \\
North East* & 75 & 88 & 100 \\
Sheffield City Region & 69 & $\mathbf{8 1}$ & $\mathbf{9 3}$ \\
\hline
\end{tabular}

${ }^{*}$ Bristol \& surrounding area

**New castle \& surrounding area

Sources: APS, ONS and Sheffield Hallam University

Sheffield City Region languishes at the bottom of this league table in terms of GVA per head and GVA per filled job. The figures also emphasise just how far London is ahead of

England's other big cities: London's GVA per head is more than two and a half times higher than in Sheffield City Region and its GVA per filled job is more than 70 per cent higher.

The 'efficiency factor' - GVA per job after adjusting for industrial and occupational mix and hours worked - shows a rather different pattern. London remains in front but its lead is much reduced and indeed may be inflated by the inability here to take full account of the capital's concentration of the very highest-paid managerial and professional jobs. In terms of efficiency, Sheffield City Region is much closer to the national average and not ou t-of-line with most other urban LEPs. On this indicator, intended to measure the efficiency with which goods and services are produced, Sheffield City Region comes in at 93 per cent of the UK average compared to 92 per cent in Greater Manchester, 91 per cent in Leeds City Region and 93 per cent in D2N2 (Derby \& Derbyshire, Notting ham and Nottinghamshire).

\footnotetext{
${ }^{7}$ C Beatty and S Fothergill (2019) op. cit.
} 


\section{Productivity by local authority}

Table 2 presents figures on productivity for each of the local authorities within Sheffield City Region. All the figures here, for 2018 , are again expressed in relation to the national average where UK=100.

All the constituent local authorities of city region have a level of output (GVA) per head below the national average, sometimes substantially so. All except Bolsover have a GVA per job below the national average, and all except Bolsover have an estimated 'efficiency factor' the value of output per job after adjusting for industry, occupation and hours worked ${ }^{8}-$ below the national average.

However, in all the constituent local authorities the 'efficiency factor' is higher than either GVA per head or GVA per job implying that, as in the city region as whole, much of the shortfall in these two measures of local productivity is rooted in structural factors. Indeed, putting aside Bolsover and Derbyshire Dales, the 'efficiency factor' in the remaining local authorities, which include the vast majority of the city region's population, is in the relative narrow range of 89 to 97 per cent of the national average.

That the differences in efficiency across the city region are modest seems an intuitively sensible observation. Sheffield City Region is a relatively compact area with sizeable commuting flows. To a significant extent the city region functions as a single large labour market and shares the same infrastructure. It is hard to see how this interconnectedness would not have resulted in broadly similar levels of efficiency across the sub-region. In particular, the three South Yorkshire boroughs of Barnsley, Doncaster and Rotherham have similarities in size and industrial history that would seem to offer a pointer to their broadly similar levels of estimated efficiency.

The figures for Bolsover are unusual. They almost certainly reflect the impact of the Sports Direct warehouse and headquarters at Shirebrook. Bolsover is a small district with relative few jobs so the inclusion of this large local employer has the potential to make a difference to the overall figures. Whereas Sports Direct employs large numbers on zero-hours contracts in its shops and indeed at its warehouse in Shirebrook, it also employs a small core staff who in recent years have received exceptionally large bonuses. The likelihood is that many of this core team are counted at the Shirebrook site, and possibly company profits too, boosting the local GVA data to an unusual extent.

The 'efficiency factor' in Derbyshire Dales is also out-of-line with other parts of the city region. This is again a small local economy but also one where tourism is a significant sector. A similarly low figure for Cornwall in our 2019 study $^{9}$ suggests that this may be because the adjustments for industry and occupation are unable to take fully into account the distinctive nature of the tourism sector.

\footnotetext{
${ }^{8}$ The adjustment for hours worked uses ONS data for Sheffield City Region as a whole because the data for individual local authorities from the government's Annual Survey of Hours and Earnings appears to be affected by sampling errors that render it unreliable.

${ }^{9} \mathrm{C}$ Beatty and S Fothergill (2019) op. cit.
} 
Table 2: Productivity by local authority, 2018, UK=100

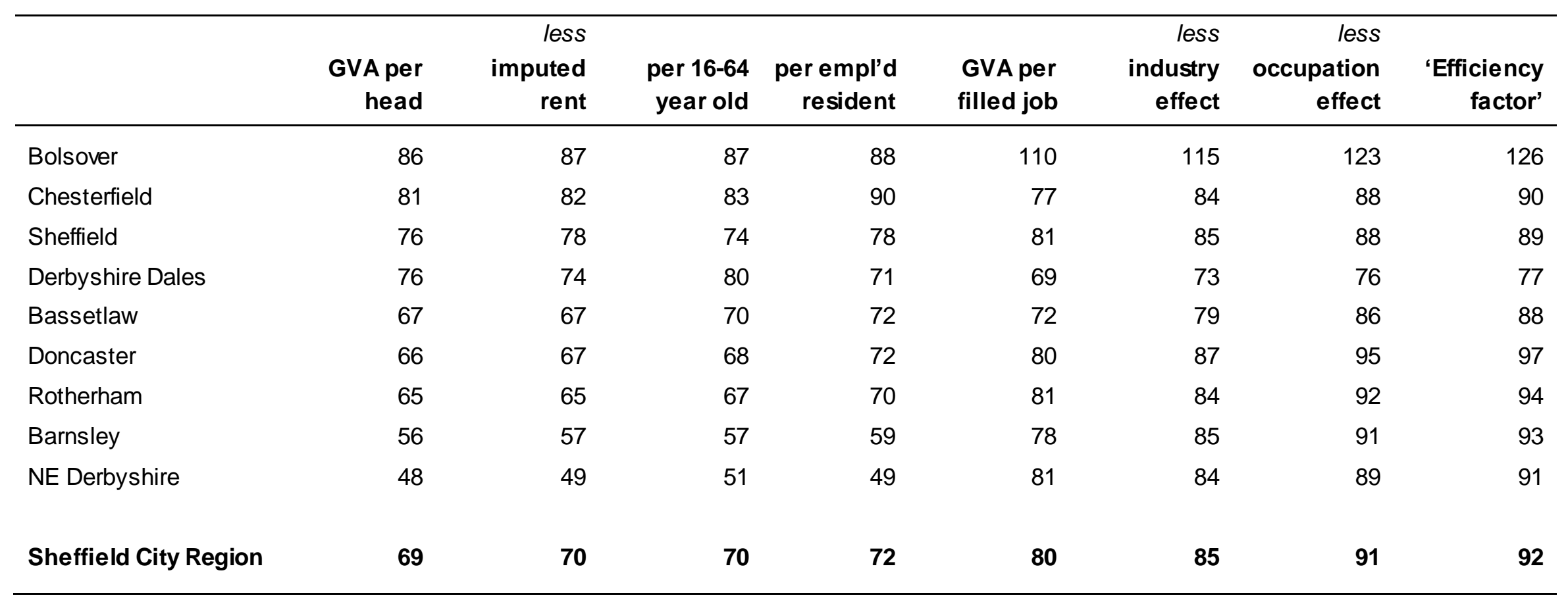

Sources: APS, ONS and Sheffield Hallam University 


\section{Trends over time}

Figure 2 shows the trends in productivity in Sheffield City Region between 2004 and 2018. Three indicators of productivity are presented here - GVA per head, GVA per filled job and the 'efficiency factor' - and in each case the local figures are again index numbers where $\mathrm{UK}=100$. The diagram therefore shows the extent to which Sheffield City Region is catching up or falling behind the national average. Because the figures for individual years fluctuate a little the diagram shows a three-year rolling average, which better exposes the underlying trends.

Figure 2: Trends in productivity in Sheffield City Region, 2004-2018

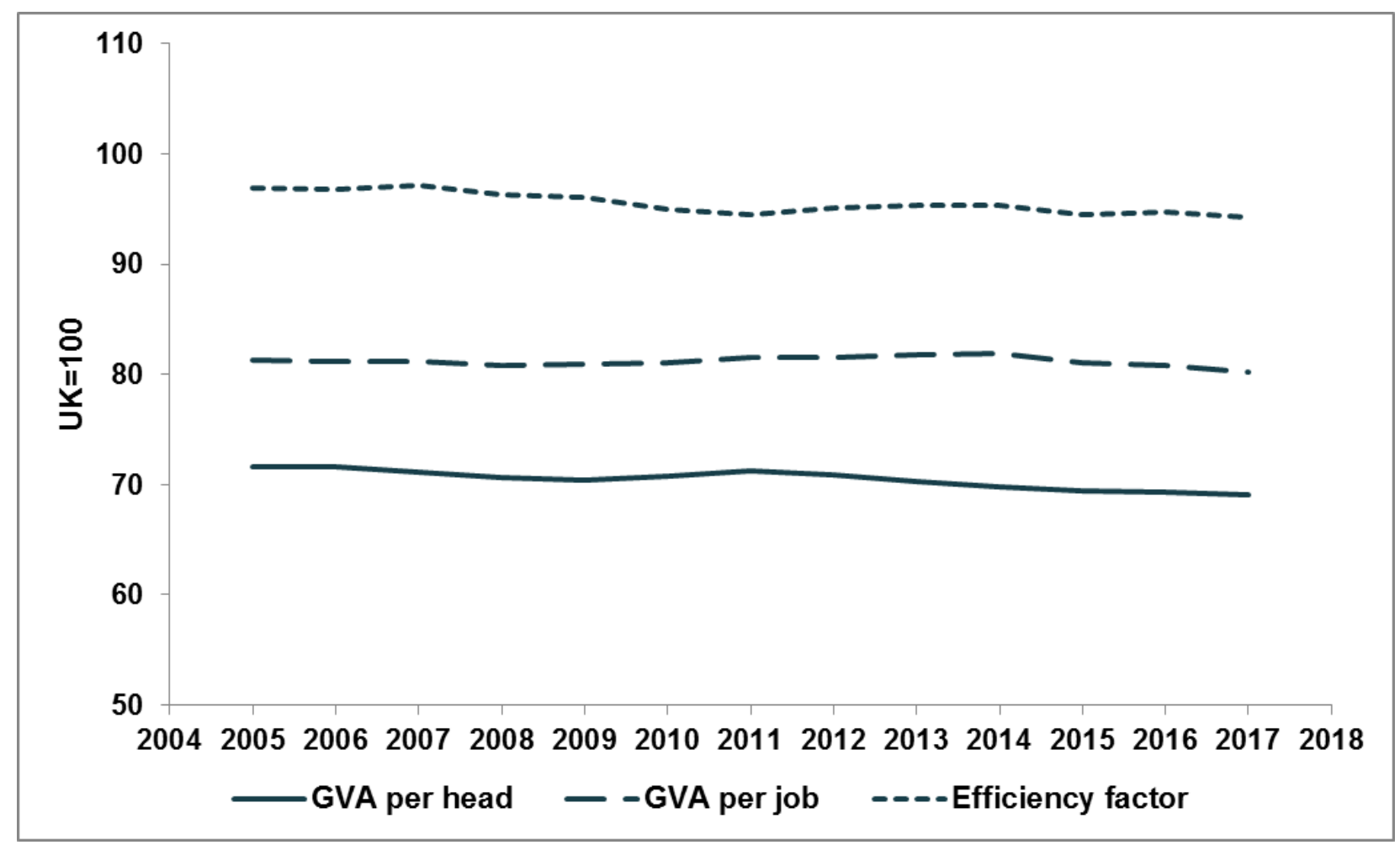

Sources: APS, ONS and Sheffield Hallam University

The most obvious observation is that there has been stability in Sheffield City Region's productivity compared to the national average. Over the whole of this period GVA per head in the city region has been around 70 per cent of the UK average, perhaps slipping marginally by a couple of percentage points. GVA per filled job has been consistently at or just above 80 per cent of the average. The estimated 'efficiency factor' has been around 95 per cent of average, again perhaps slipping by a couple of percentage points over the period as a whole.

In short, the productivity of Sheffield City region does not appear to be catching up with the national average. Moreover, if it is falling further behind, albeit very marginally, this could be no more than a reflection of the recent growth in the local economy of low-value sectors such as warehousing and logistics. 
Figure 3: Trends in productivity in the South Yorkshire boroughs, 2004-2018

Barnsley

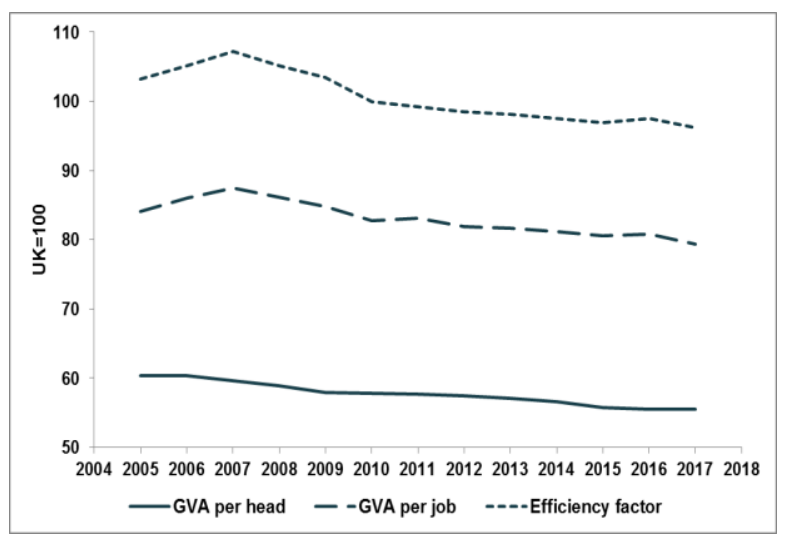

Rotherham

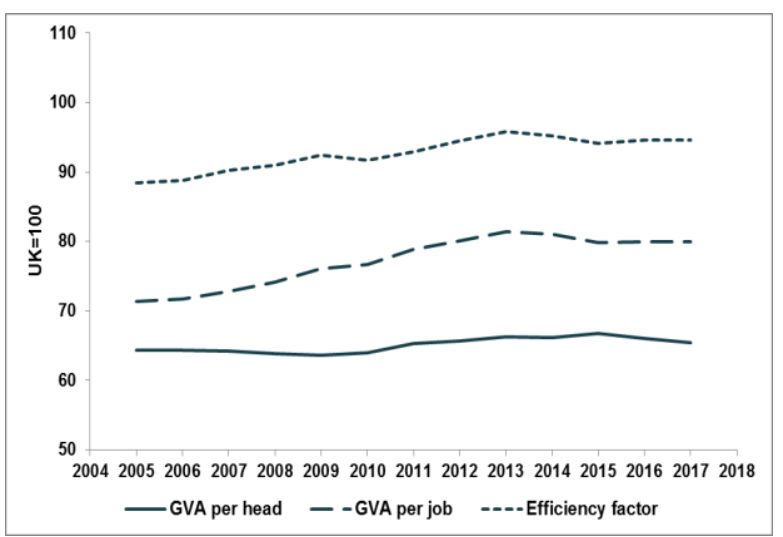

Doncaster

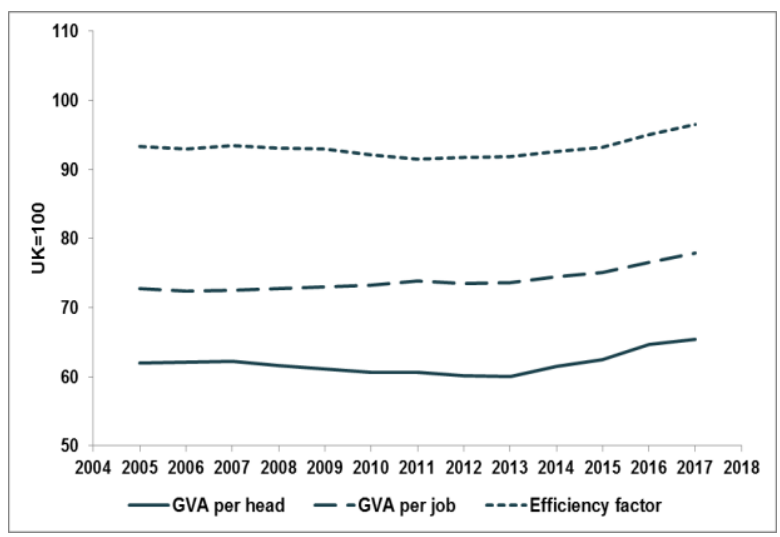

Sheffield

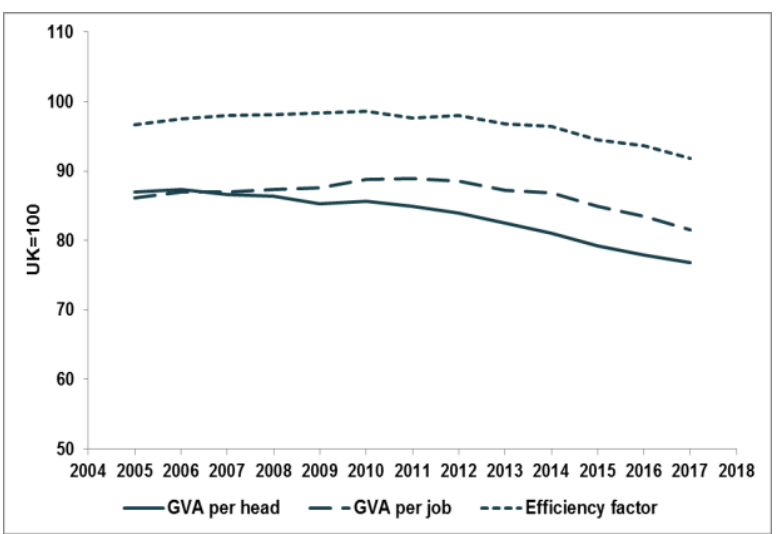

Sources: APS, ONS and Sheffield Hallam University 
Figure 3 shows the trends in productivity in each of the four South Yorkshire boroughs ${ }^{10}$, again on a three-year rolling average basis and indexed again st the national average.

Barnsley has a GVA per head that has been consistently lower than the other boroughs, and one that has fallen a little over time. This reflects Barnsley's present-day role, following the loss of the local coal industry, as home for many people who work elsewhere.

Barnsley's GVA per filled job - jobs located in the borough - is much higher, though has been tending to fall relative to the national average. In terms of the efficiency of production (i.e. after adjusting for industrial and occupational mix and hours worked) Barnsley is close to the national average but the trend is again downwards. Part of the apparent slide in productivity in Barnsley is likely to be a reflection of its changing industrial structure, in particular the local growth of employment in warehousing and logistics, which at one level has been a success for regeneration policy but at another has weighed down on the productivity figures because so much of the local activity in this sector is low-wage and lowproductivity. The adjustment for industry mix used here is based on data for a single point in time (2011) and therefore unable to take account of these changes in the composition of local employment.

Doncaster also has a low GVA per head, though one that appears now to be increasing. The Doncaster economy too was distorted by the loss of the coal industry but in recent years local job growth has been strong, not least because the borough has been able to take advantage of excellent road and rail connections and a plentiful supply of developable flat land. Doncaster's GVA per job also appears to be on a rising trajectory relative to the national average. The estimated efficiency of production in Doncaster has been below par but in the last few years appears to have converged towards the national average, matching the level in Barnsley for example.

Rotherham has seen a stable level of GVA per head, just below two-thirds of the national average. Over the period as a whole its GVA per job has moved closer to the national average, as has the borough's estimated efficiency of production, to a level that matches Barnsley and Doncaster. Quite what underpins these trends is unclear but they may owe something to a changing mix of industries. Owing to Rotherham's proximity to Sheffield there has probably been a loss of low-wage, low-productivity jobs in retailing and leisure activities that have tended to gravitate to the main urban centres - which would paradoxically have boosted the average GVA per job in the borough. The labour shed by Rotherham's steel industry will also have tended to boost the output per job among the remaining workforce.

She ffield displays declining GVA per head, relative to the UK average, alongside a recent but less marked fall in GVA per filled job and a recent fall in the estimated efficiency of production. The declining GVA per head almost certainly owes something to the city's expansion in student numbers, because students are included in the population head-count but contribute little directly to GVA. Falling GVA per job may reflect the expansion of lowwage, low-productivity services - bars, cafes, taxis, delivery drivers - that have become a marked feature of urban life. Whether the recent fall in estimated efficiency in Sheffield is a

\footnotetext{
${ }^{10}$ The data for the remaining smaller local authorities within Sheffield City Region appears less robust and is therefore not presented here.
} 
short-term blip - prior to the mid-2010s the estimates were stable at just below the national average - remains to be seen.

\section{Differences between industries}

Table 3 compares output (GVA) per job in each industry in Sheffield City Region with the UK average ${ }^{11}$. Overall, GVA per filled job in the city region is roughly four-fifths of the national average but this table reveals substantial variation between individual industries in the local economy.

Table 3: GVA per job by industry, Sheffield City Region (SCR), 2018

\begin{tabular}{lrrrr}
\hline & $\begin{array}{r}\text { Employment } \\
\text { SCR }\end{array}$ & $\begin{array}{r}\text { GVA per job } \\
\text { SCR }\end{array}$ & $\begin{array}{r}\text { GVA per job } \\
\text { UK } \\
\text { I pa }\end{array}$ & $\begin{array}{r}\text { GVA per job } \\
\text { (ratio) } \\
\text { UK=100 }\end{array}$ \\
\hline Other services & & 58,900 & 47,100 & 125 \\
Education & 11,500 & 44,700 & 40,500 & 110 \\
Heath \& social work & 76,500 & 34,600 & 35,500 & 98 \\
Construction & 118,500 & 72,900 & 75,900 & 96 \\
Wholesale, retail, motor trade & 36,000 & 38,800 & 42,200 & 92 \\
Public administration \& defence & 124,000 & 60,400 & 68,500 & 88 \\
Real estate & 33,500 & 113,200 & 133,800 & 85 \\
Agriculture, energy \& water & 9,500 & 62,100 & 74,700 & 83 \\
Administrative \& support services & 16,700 & 30,000 & 36,700 & 82 \\
Transport \& storage & 57,500 & 43,000 & 53,300 & 81 \\
Accommodation \& food services & 45,500 & 18,300 & 22,900 & 80 \\
Manufacturing & 53,500 & 50,300 & 75,100 & 67 \\
Professional, scientific \& technical & 92,500 & 34,500 & 54,700 & 63 \\
Information \& communication & 46,500 & 61,100 & 103,500 & 59 \\
Finance \& insurance & 23,500 & 69,200 & 128,700 & 54 \\
Arts, entertainment \& recreation & 17,000 & 20,200 & 39,500 & 51 \\
All industries & 19,500 & 47,100 & 60,000 & $\mathbf{7 9}$ \\
\hline
\end{tabular}

Sources: BRES, ONS

\footnotetext{
${ }^{11}$ These calculations use Business Register and Employment Survey (BRES) data on the number of workplace jobs, which excludes the self-employed in businesses that are not registered for VAT. This differs from the more inclusive employment data underpinning the ONS estimates of GVA per filled job, which is not available disaggregated by industry. The employment data for Northern Ireland included in the UK estimates comes from the Northern Ireland Statistics and Research Agency. The data on GVA by industry is from ONS.
} 
A number of industries have a GVA per job that is above or close to the UK average. These include education, health \& social work, construction and other services ${ }^{12}$, which together account for just under a third of total employment in the city region. The wholesale, retail \& motor trade and public administration, which account for a further 20 per cent of employment, are not too far behind.

It is not difficult to explain why GVA per job in these sectors should be close to the national average. The way in which a school, a hospital, a building site or a supermarket is organised, and thereby its labour productivity, seems unlikely to vary a great deal across the country. Management practices, technology, the qualifications required of the workforce, and indeed the performance expectations of national companies and publ ic sector bodies will on the whole be standardised across the country. In these sectors we might therefore expect only modest variation in productivity from place to place and the figures for Sheffield City Region seem to bear this out.

At the other end of the spectrum there are a number of industries - manufacturing, professional, scientific \& technical services, information \& communication, finance \& insurance, and arts, entertainment \& recreation - in which GVA per job in Sheffield City Region is at or below two-thirds of the national average. These industries account for a quarter of all employment in the city region.

The explanations here are probably varied. In part what the low GVA per job figures are likely to reflect are detailed differences between the activities in Sheffield City Region and the national average, especially where the national average is heavily weighted by activities in London. For example, finance \& insurance in Sheffield City Region includes few of the high-end banking activities found in London that boost recorded GVA. Similar explanations probably apply within professional services, information \& communication (including the media), and arts \& entertainment. What is also likely is that the below-average GVA per job in some industries reflects the local mix of occupations - the concentration of managerial and professional jobs in other parts of the country (especially London) and the predominance of routine production and service delivery in places such as Sheffield City Region.

As noted earlier, adjusting for the mix of occupations within each industry narrows the gap between local and national GVA per job by around six percentage points. Table 4 replicates this adjustment for the mix of occupations for eight broad sector s within Sheffield City Region ${ }^{13}$. This calculates what would have been GVA per job in each sector if each occupational group within the sector had the UK average GVA for that occupation, using UK average gross hourly earnings in each occupation as a proxy for GVA. The impact of occupational mix is an addition or subtraction from the GVA per job in each sector. Adjustment for occupational mix brings a sector with a predominance of low-grade jobs in the local economy (compared to the national average for that sector) closer to the UK average.

\footnotetext{
12 'Other services' covers membership organisations (e.g. trade unions, churches), repair of computers, personal \& household goods, and other personal services (e.g. hairdressers, laundry)

${ }^{13}$ Data on occupation by industry for local areas is not available to allow a finer-grain industrial breakdown.
} 


\begin{tabular}{lrr}
\hline & $\begin{array}{r}\text { GVA per job } \\
\text { UK=100 }\end{array}$ & $\begin{array}{r}\text { Adjusted for } \\
\text { occupational mix } \\
\text { UK=100 }\end{array}$ \\
\hline Public administration, education \& health & 98 & 96 \\
Construction & 96 & 106 \\
Distribution, hotels, restaurants & 91 & 107 \\
Agriculture, energy \& water & 84 & 97 \\
Other services & 79 & 90 \\
Finance, professional \& admin services & 74 & 76 \\
Manufacturing & 67 & 76 \\
Transport \& communication & 64 & 74 \\
All industries & 79 & $\mathbf{8 6}$ \\
\hline
\end{tabular}

Sources: BRES, ONS and Sheffield Hallam University

This adjustment for occupational mix divides the city region's economy into two groups: the sectors where local productivity is at or close to the national average, broadly covering the industries in which consistency across the country might be expected; and the remaining sectors - finance, professional \& administrative services, manufacturing, and transport \& communication - in which local productivity still appears to be well adrift of the national average.

In finance, professional \& administrative services and in transport \& communication the explanation probably lies in the mix of activities within each sector. A comparison between Sheffield City Region and the UK average does not really compare like-with-like because within finance and professional services, for example, the city region lacks so many of the higher value-added activities found in London and a number of other places. The city region's figures for transport \& communications will also be weighted-down by, amongst other factors, a specialisation in low value-added logistics.

The figures for manufacturing are harder to explain, and perhaps concerning. In Sheffield City Region this sector has a GVA per job of just 67 per cent of the UK average and only 76 per cent of the UK average after adjusting for occupational mix. Table 5 disaggregates GVA within manufacturing into four broad industrial groups ${ }^{14}$. It shows that the city region's low GVA per job (relative to the UK average) is found in all four groups. The largest group in employment terms - metals, electrical \& machinery, a traditional local specialism - has the lowest GVA per job at just 59 per cent of the UK average.

\footnotetext{
${ }^{14}$ The published data on GVA by industry for local areas does not allow a finer-grain disaggregation.
} 
Table 5: Productivity within manufacturing, Sheffield City Region(SCR), 2018

\begin{tabular}{|c|c|c|c|c|}
\hline & $\begin{array}{r}\text { Employment } \\
\text { SCR }\end{array}$ & $\begin{array}{r}\text { GVA per job } \\
\text { SCR } \\
£ \text { pa }\end{array}$ & $\begin{array}{r}\text { GVA per job } \\
\text { UK } \\
£ \text { pa }\end{array}$ & $\begin{array}{r}\text { GVA per job } \\
\text { (ratio) } \\
\text { UK }=100\end{array}$ \\
\hline Food, drink, textiles \& clothing & 16,750 & 60,000 & 71,200 & 84 \\
\hline Other manufacturing & 13,000 & 41,800 & 54,300 & 77 \\
\hline $\begin{array}{l}\text { Wood, petroleum, chemicals etc. } \\
\text { Metals, electrical \& machinery }\end{array}$ & $\begin{array}{l}22,350 \\
39,700\end{array}$ & $\begin{array}{l}54,600 \\
47,600\end{array}$ & $\begin{array}{l}88,200 \\
81,000\end{array}$ & $\begin{array}{l}62 \\
59\end{array}$ \\
\hline All manufacturing & 92,500 & 50,300 & 75,100 & 67 \\
\hline
\end{tabular}

Sources: BRES, ONS

The low productivity of Sheffield City Region's manufacturing sector is puzzling. It could point to inefficiency, which would be alarming. However, in a competitive market inefficiency is usually punished - firms shrink and go out of business - whereas there is clearly a substantial manufacturing sector that continues to operate across the city region, no doubt with varying degrees of success.

One possibility is that there are further structural influences at work - that within each of the four industry groups the city region may specialise in specific industries that are associated with low value-added. There may be something in this, just as the occupational mix within the local manufacturing sector goes some way to accounting for the gap between local and national GVA per job. Another possibility is that the city region's manufacturing sector is labour-intensive, because capital-intensive production normally generates higher GVA per job. There may be labour-intensive local firms that have found a market niche in which they can successfully operate year after year without having to significantly expand or up -grade their stock of plant and machinery.

The apparently low productivity in Sheffield City Region's manufacturing sector is potentially concerning because manufacturing still occupies a pivotal role in the local economy. In 2018 , manufacturing employed 92,500 people in the city region, or 12 percent of all employment ${ }^{15}$. This is well down on historic levels but manufacturing supports large numbers of other local jobs through its supply chain, in sectors such as transport and business services for example, and through the wages and salaries of its employees spent in the local economy. In this sense the manufacturing sector remains one of the drivers of the local economy as a whole. By contrast, the much larger local numbers of jobs in sectors such as retailing, health, public administration and schools are mostly tied to the local population and local spending. Unlike manufacturing, they are mostly not independent drivers of local economic growth.

\footnotetext{
${ }^{15}$ BRES data excluding the self-employed not registered for VAT.
} 
Seven main conclusions emerge from the empirical evidence in this report.

First, Sheffield City Region displays low productivity on two widely used indicators GVA per head and GVA per job. This is not a new observation and most of the local players in economic development will already be well aware of this fact but the gap between the city region and the national average is substantial - around 30 percentage points on GVA per head and 20 percentage points on GVA per job.

Second, the efficiency of production in the city region is much closer to the national average - a gap of just 8 percentage points on the figures presented here and, given the limitations of the estimates in capturing the full impact of structural factors, the real gap may be somewhat smaller. Sheffield City Region's GVA per job lags so far behind the UK figure mainly because the city region's economy is skewed towards industries and occupations that have below average value-added across the UK as a whole. The city region is not, it seems, especially inefficient at the economic activities it actually undertakes.

Third, the estimated efficiency of production in Sheffield City Region is not out of line with other English city regions, including Manchester, Leeds and Nottingham/Derby, even though the city region lags behind in terms of GVA per head and GVA per job.

Fourth, putting aside Bolsover and Derbyshire Dales, where measurement issues come into play, the differences in efficiency across the city region appear to be modest, which is what might be expected in a relatively compact and inter-connected local labour market. In particular, Barnsley, Doncaster and Rotherham, which share a great deal in terms of size and industrial history, appear to have very similar levels of efficiency.

Fifth, relative to the national average, productivity across Sheffield City Region as a whole has been broadly stable over the last decade and a half. The city region is neither catching up nor falling a great deal further behind. Borough by borough within South Yorkshire the trends appear a little more complex though some of the changes are likely to be attributable to the changing mix of industries.

Sixth, there are substantial differences in productivity between industries. A number of sectors - education, health, construction and retailing - have a level of GVA per job in the city region that is at or close to the national average whereas several others - professional services, finance, arts \& leisure and manufacturing - have a local GVA per job that is far behind the UK average. These differences cannot be explained by occupational mix, though this is a contributory factor. In at least some sectors the shortfall is likely to reflect compositional factors, for example the comparative absence of the very high value-added jobs in finance and professional services found in London. 
Seventh, productivity in Sheffield City Region's manufacturing sector is well below the national average. This is evident in the figures for GVA per job and remains the case after adjusting for occupational mix. Low productivity also appears to characterise each of the main parts of the local manufacturing sector. Whether this is a problem, reflecting 'inefficiency', is unclear. It may be that the city region's manufacturing sector specialises in labour-intensive niches rather than the capital-intensive activities that tend to boost productivity elsewhere. Either way, the shortfall in GVA per job in manufacturing is real enough.

\section{Policy implications}

At a time of national and international economic crisis, low productivity is not the primary problem. In the short-term the challenge facing Sheffield City Region is to keep intact as much as possible of its stock of businesses and to restore output and employment to precrisis levels but, as we noted in the introduction, as the economy emerges from recession the post-coronavirus world will inherit much the same capital stock, workforce and infrastructure that was previously in place. The speed and extent of recovery may vary across the country but there is no reason to suppose that the underlying gaps in productivity will have gone away even if there are changes in the precise ranking of local areas. This report does not chart a way out of the crisis but it offers important pointers for public policy in the post-crisis world.

The first pointer is about understanding, perception and marketing. It is too easy to slip from the observation that GVA per head and GVA per job in Sheffield City Region are well behind the national average into denigrating local businesses and the local workforce. Local representatives may refrain from doing so but it is a short step for politicians and their advisers in Westminster to assume that because of this data the city region has a 'problem'. If Sheffield City Region does have a productivity problem, what the evidence here indicates is that it is far less than the headline official figures would suggest and no worse, in fact, than in most of England's other main urban areas outside London. In terms of the efficiency with which goods and services are produced in the city region the shortfall is modest at best.

This observation is important for how the city region projects itself to the world, to potential investors in particular. The estimates of efficiency indicate that there is little or no reason why a business investment in Sheffield City Region should prove any less productive or successful than a comparable investment in another part of the UK. Putting aside businesses that have specialist requirements pointing them to specific places elsewhere, Sheffield City Region is not an inherently inefficient or uncompetitive location and it has plenty of marketable assets in terms of its workforce, business infrastructure and liveability .

The second pointer is about how to raise productivity in the city region. The shortfalls in GVA per head and GVA per job are real enough but the principal solution lies in creating more jobs and better jobs. There is still plenty of labour market slack in the local economy and in the short-run the crisis will make things worse. For example, in 2019 the employment 
rate (the share of adults of working age in employment) in Sheffield City Region was almost six percentage points lower than the average in South East England, an economy operating much closer to full employment ${ }^{16}$. Raising employment in Sheffield City Region would boost GVA per head but not necessarily GVA per job.

The problem with GVA per job is that at present the city region has a mix of industries and occupations that drags down the figures. To boost GVA per job requires more jobs in high value-added sectors and more jobs in high value-added occupations. In truth, there are limits to what might be achievable: even with all the right policies in place it seems unlikely that Sheffield City Region will ever match the concentration of very high value-added financial and professional services found in London. However, it is probably possible to make progress. In practice, this is likely to follow from actions to attract new businesses, upgrade existing businesses and shift the centre of gravity of local labour demand and supply towards higher-grade, better-paid work. The present report identifies the challenge but it stops short of pinpointing the solutions, which need to be addressed in detail by local partners in the city region.

The limitations of a single-minded pursuit of higher productivity, via higher value-added jobs, should nevertheless be noted. For example, one of Sheffield City Region's bigger successes in recent years - the attraction of so many jobs in logistics, especially to the former coalfields - has probably worked against an improvement in the figures on GVA per job. The coronavirus crisis too has highlighted that many of the front-line jobs that society needs most, in health and social care for example, are not necessarily those that score highest in economic statistics on 'value-added'. The pursuit of higher productivity needs to be balanced against other consideration.

The third pointer is the need for research into low productivity in manufacturing. The figures for the city region are both puzzling and potentially alarming. Manufacturing still occupies a particularly pivotal position in local economies, including in Sheffield City Region. With manufacturing productivity in the city region at such apparently low levels there is an urgent question about whether this is sustainable and, if not, whether something can be done to improve the situation. More generally, in as far as productivity ultimately underpins incomes and living standards the apparently lowproductivity in Sheffield City Region's manufacturing sector is a brake on local prosperity even if the businesses themselves are able to find ways of muddling through.

Sheffield City Region would be well advised to commission substantial new research into productivity in the local manufacturing sector. This would be likely to result not only in a clearer assessment of the problem but also help identify practical actions in terms of business support, workforce training and public investment that could help deliver better outcomes.

${ }^{16}$ APS data for October 2018 to September 2019 


\section{CRESR \\ Sheffield Hallam University \\ City Campus \\ Sheffield S1 1WB \\ +44(0)1142253073 \\ e: cresr@shu.ac.uk \\ w: shu.ac.uk/cresr}

ISBN: 978-1-84387-431-7

DOI: $10.7190 /$ cresr.2020.6013989709

\section{Sheffield Centre for \\ Hallam Regional Economic University and Social Research}




\section{Sheffield Hallam University}

\section{Productivity in Sheffield City Region}

BEATTY, Christina <http://orcid.org/0000-0003-0943-9979> and FOTHERGILL, Steve Available from the Sheffield Hallam University Research Archive (SHURA) at: http://shura.shu.ac.uk/26344/

\section{Copyright and re-use policy}

Please visit http://shura.shu.ac.uk/26344/ and http://shura.shu.ac.uk/information.html for further details about copyright and re-use permissions. 